\title{
Differential Expression of Exons 1a and 1c in mRNAs for Sterol Regulatory Element Binding Protein-1 in Human and Mouse Organs and Cultured Cells
}

\author{
lichiro Shimomura, Hitoshi Shimano, Jay D. Horton, Joseph L. Goldstein, and Michael S. Brown
}

Department of Molecular Genetics, University of Texas Southwestern Medical Center, Dallas, Texas 75235

\begin{abstract}
The $5^{\prime}$ end of the mRNA-encoding sterol regulatory element binding protein-1 (SREBP-1) exists in two forms, designated 1a and 1c. The divergence results from the use of two transcription start sites that produce two separate $5^{\prime}$ exons, each of which is spliced to a common exon 2. Here we show that the ratio of SREBP-1c to 1a transcripts varies markedly among organs of the adult mouse. At one extreme is the liver, in which the $1 \mathrm{c}$ transcript predominates by a 9:1 ratio. High 1c:1a ratios are also found in mouse adrenal gland and adipose tissue and in human liver and adrenal gland. At the other extreme is the spleen, which shows a reversed 1c:1a ratio (1:10). In five different lines of cultured cells, including the HepG2 line derived from human hepatocytes, the 1a transcript predominated (1c:1a ratio $<1: 2)$. In mouse 3T3-L1 preadipocytes, the 1a transcript was present, but the 1c transcript was not detectable. When these cells were differentiated into adipocytes by hormone treatment in culture, the amount of 1a transcript rose markedly (8.2fold), and the $1 \mathrm{c}$ transcript remained virtually undetectable. We conclude that the SREBP-1a and 1c transcripts are controlled independently by regulatory regions that respond differentially to organ-specific and metabolic factors. ( $J$. Clin. Invest. 1997. 99:838-845.) Key words: SREBP-1 • alternative splicing $\cdot$ cholesterol $\bullet$ fatty acids $\bullet$ liver $\cdot$ adipocytes
\end{abstract}

\section{Introduction}

Sterol regulatory element binding proteins (SREBPs) ${ }^{1}$ are membrane-bound transcription factors that control the metabolism of cholesterol and fatty acids in animal cells (1-5). The SREBPs are tripartite proteins consisting of: $(a)$ an $\mathrm{NH}_{2}$-terminal domain of $\sim 480$ amino acids that is a transcriptional activator of the basic-helix-loop-helix-leucine zipper family; $(b)$ a hairpin membrane anchor domain of $\sim 80$ amino acids com-

Address correspondence to Joseph L. Goldstein or Michael S. Brown, Department of Molecular Genetics, University of Texas Southwestern Medical Center, 5323 Harry Hines Blvd., Dallas, TX 75235. Phone: 214-648-2141; FAX: 214-648-8804.

Received for publication 1 November 1996 and accepted in revised form 12 December 1996.

1. Abbreviations used in this paper: HMG CoA, 3-hydroxy-3-methylglutaryl CoA; RT-PCR, reverse transcriptase PCR; RACE, rapid amplification of cDNA ends; SREBP, sterol regulatory element binding protein.

J. Clin. Invest.

(C) The American Society for Clinical Investigation, Inc. 0021-9738/97/03/0838/08 \$2.00

Volume 99, Number 5, March 1997, 838-845 prising two transmembrane segments separated by a 31-amino acid hydrophilic loop; and (c) a $\mathrm{COOH}$-terminal domain of $\sim 590$ amino acids that plays a regulatory role $(6,7)$. Newly synthesized SREBPs are bound to cell membranes in a hairpin fashion. The $\mathrm{NH}_{2}$-terminal and $\mathrm{COOH}$-terminal segments face the cytosol and the intervening hydrophilic loop projects into the lumen of the nuclear envelope and endoplasmic reticulum (6). In cholesterol-depleted cells a two-step proteolytic process releases the $\mathrm{NH}_{2}$-terminal fragments (8), allowing them to enter the nucleus where they bind to sterol regulatory elements and activate transcription of genes encoding enzymes of cholesterol synthesis (3-hydroxy-3-methylglutaryl coenzyme A [HMG CoA] synthase, $\mathrm{HMG}$ CoA reductase, farnesyl diphosphate synthase, squalene synthase), cholesterol uptake (LDL receptor), and fatty acid synthesis (acetyl CoA carboxylase and fatty acid synthase) (1-5). When tissue culture cells are overloaded with sterols, the proteolytic process is inhibited, the $\mathrm{NH}_{2}$-terminal fragments are not released, and transcription of the target genes declines $(1,8)$.

Two SREBPs, designated SREBP-1 and -2, have been isolated and cloned from several mammalian species (9-13). Human SREBP-1 and -2 are $\sim 50 \%$ identical in amino acid sequence (10). They share the tripartite structure, and they both have the capacity to activate the same genes. Although the two proteins can form heterodimers, this does not appear necessary for their function (10). In tissue culture cells such as Chinese hamster ovary cells or human HeLa cells, the proteolytic processing of the two SREBPs is regulated coordinately. Cleavage of both proteins is enhanced by sterol depletion and inhibited by sterol supplementation $(1,8)$. A different pattern of regulation was observed in hamster liver (14). In the basal state on a normal chow diet, SREBP-1 was proteolytically processed, and the $\mathrm{NH}_{2}$-terminal fragment was found in the nucleus. SREBP-2 was present in smaller amounts, and all of it was membrane bound. When the livers were depleted of sterols by treating the animals with a combination of a cholesterol synthesis inhibitor (lovastatin) and a bile acid binding resin (Colestipol), the amount of SREBP-2 rose, and the efficiency of its proteolytic processing increased. Paradoxically, the proteolytic processing of SREBP-1 was inhibited. This reciprocal regulation suggested that SREBP-1 and -2 might be playing different roles in the liver (14). A possible clue stems from the observation that SREBP-1, but not SREBP-2, exists in several different forms as a result of alternative exon usage $(9,15)$.

The cloning of human SREBP-1 from a HeLa cell library yielded cDNAs with two different $5^{\prime}$ ends (9). These are derived from two different promoters that give rise to two different $5^{\prime}$ exons (exons 1a and 1c), both of which are spliced to a common exon 2 (reference 15; see Fig. 1). The version designated SREBP-1a contains a 5 ' exon that encodes a long acidic sequence of 29 amino acids, 8 of which are negatively charged. This sequence functions in concert with four negativelycharged amino acids from exon 2 to constitute a transcriptional activator of 42 amino acids. Deletion of this region (residues $1-$ 
51) allows SREBP-1a to bind to the SRE-1 sequence, but it can no longer activate transcription, and so it becomes a dominant negative regulator (11). The alternative form, designated SREBP-1c, contains a $5^{\prime}$ exon that encodes only 5 amino acids, one of which is negatively charged (reference 9; see Fig. 1). Recent experiments in transfected cells have shown that SREBP-1c is a much weaker activator of transcription than SREBP-1a when both are expressed at levels approximating those found in nontransfected cells (15a).

In addition to the alternative coding sequences at the $5^{\prime}$ end, SREBP-1 mRNAs can have alternative coding sequences at the $3^{\prime}$ end $(9,15)$. One version terminates with exons $18 \mathrm{a}$ and 19a. This version was originally found in a cDNA that contained the SREBP-1a sequence at the $5^{\prime}$ end. The other version contains alternate exons 18c and 19c. Transfection of cells with cDNAs encoding SREBP-1a with exons 18a and 19a yields a protein that is cleaved efficiently in sterol-depleted cells to generate the active $\mathrm{NH}_{2}$-terminal fragment (7). Cleavage of this protein is suppressed almost completely by sterol overloading. In contrast, the version of SREBP-1a that terminates in exons $18 \mathrm{c}$ and $19 \mathrm{c}$ is cleaved at lower efficiency, and there is no suppression by sterols (7). In CHO cells exons $18 \mathrm{a}$ and 19a predominate (11). As a result, cleavage of endogenous SREBP-1 is regulated efficiently by sterols. So far, exons $18 \mathrm{c}$ and $19 \mathrm{c}$ have been observed only in the human genome (15). We have been unable to find exons $18 \mathrm{c}$ or $19 \mathrm{c}$ in the mouse genome or in cDNAs cloned from mouse liver.

A rat cDNA designated ADD1, which encodes SREBP-1, was cloned by Tontonoz et al. (13) from a rat adipocyte library. ADD1 contains the SREBP-1c sequence at the $5^{\prime}$ end. The $3^{\prime}$ end is difficult to interpret. Computer alignment of the human SREBP-1 and rat ADD1 cDNA sequences reveals that the $3^{\prime}$ end of ADD1 corresponds to the $3^{\prime}$ end of SREBP-1a at the DNA level. The situation is confused at the protein level because there appears to be five single nucleotide additions or deletions in the ADD1 sequence that change the reading frame and introduce a premature terminator codon after amino acid 920. If one corrects for these apparent aberrations, which occur in the region corresponding to exons 16 and 17 of human SREBP-1, the translated sequence of the $3^{\prime}$ end of rat ADD1 corresponds to human SREBP1a.

In the current studies, we have focussed on the alternative versions of exon 1 of SREBP-1, which are designated 1a and $1 c$, respectively. We have devised RNase protection assays to quantify the two transcripts, and we have found that the 1a exon predominates in all five cultured cell lines studied to date, including mouse 3T3-L1 cells that have differentiated into adipocytes. In contrast, the 1c exon predominates in liver, white and brown adipose tissue, adrenal gland, and several other tissues of the adult mouse.

\section{Methods}

Materials and methods. We obtained all restriction enzymes and modifying enzymes from New England Biolabs (Boston, MA), $\left[\alpha{ }^{-32} \mathrm{P}\right] \mathrm{CTP}$ (3,000 Ci/mmol) from Amersham Corp. (Arlington Heights, IL), and other chemicals from Sigma Chemical Co., (St. Louis, MO). Sequencing reactions were performed on a DNA sequencer by the dideoxy chain termination method. Oligonucleotides were synthesized on a DNA synthesizer (380A; Applied Biosystems). Plasmid DNA was prepared with Plasmid Maxi kits (Qiagen, Chatsworth, CA). Total

Table I. Sequences of PCR Primers for Cloning cDNA Fragments

\begin{tabular}{|c|c|c|c|c|}
\hline cRNA Probe & $\begin{array}{l}\text { Primer } \\
\text { pair }\end{array}$ & Primer sequences & $\begin{array}{l}\mathrm{PCR} \\
\text { product }\end{array}$ & Reference \\
\hline \multicolumn{3}{|l|}{ Mouse } & \multicolumn{2}{|l|}{$b p$} \\
\hline \multirow[t]{2}{*}{ SREBP-1a } & $5^{\prime}$ & 5'-TAGTCCGAAGCCGGGTGGGCGCCGGCGCCAT-3' & \multirow[t]{2}{*}{106} & \multirow[t]{2}{*}{ This pape } \\
\hline & $3^{\prime}$ & 5'-GATGTCGTTCAAAACCGCTGTGTGTCCAGTTC-3' & & \\
\hline \multirow[t]{2}{*}{ SREBP-1c } & $5^{\prime}$ & 5'-ATCGGCGCGGAAGCTGTCGGGGTAGCGTC-3' & \multirow[t]{2}{*}{116} & \multirow[t]{2}{*}{ This paper } \\
\hline & $3^{\prime}$ & 5'-ACTGTCTTGGTTGTTGATGAGCTGGAGCAT-3' & & \\
\hline \multirow[t]{2}{*}{ SREBP-2 } & $5^{\prime}$ & 5'-CACAATATCATTGAAAAGCGCTACCGGTCC-3' & \multirow[t]{2}{*}{200} & \multirow[t]{2}{*}{ This pape } \\
\hline & $3^{\prime}$ & 5'-TTTTTCTGATTGGCCAGCTTCAGCACCATG-3' & & \\
\hline \multirow[t]{2}{*}{ LDL receptor } & $5^{\prime}$ & 5'-GAAGTCGACACTGTACTGACCACC-3' & \multirow[t]{2}{*}{210} & \multirow[t]{2}{*}{19} \\
\hline & $3^{\prime}$ & 5'-СТССТCATTCССТCTGCCAGCCAT-3' & & \\
\hline \multirow[t]{2}{*}{ HMG CoA synthase } & $5^{\prime}$ & 5'-TATGATGGTGTAGATGCTGGGAAGTATACC-3' & \multirow[t]{2}{*}{224} & \multirow[t]{2}{*}{20,21} \\
\hline & $3^{\prime}$ & 5'-TCAAACAGCTGCATCAAATTAG(T/A)CTTCAC-3' & & \\
\hline \multirow[t]{2}{*}{ HMG CoA reductase } & $5^{\prime}$ & 5'-GCAATAGGTCTTGGTGGAGGTGCCAGC-3' & \multirow[t]{2}{*}{269} & \multirow[t]{2}{*}{22,23} \\
\hline & $3^{\prime}$ & 5'-GAAATCATGTTCATCCCCATGGCATC-3' & & \\
\hline \multirow[t]{2}{*}{ Lipoprotein lipase } & $5^{\prime}$ & 5'-GTGGCCGCAGCAGACGCAGGAAGA-3' & \multirow[t]{2}{*}{355} & \multirow[t]{2}{*}{24} \\
\hline & $3^{\prime}$ & 5'-CATCCAGTTGATGAATCTGGCCAC-3' & & \\
\hline \multirow[t]{2}{*}{$\beta$-actin } & $5^{\prime}$ & 5'-GGTCGTACCACAGGCATTGTGATG-3' & \multirow[t]{2}{*}{80} & \multirow[t]{2}{*}{25} \\
\hline & $3^{\prime}$ & 5'-GGAGAGCATAGCCCTCGTAGATGG-3' & & \\
\hline \multicolumn{5}{|l|}{ Human } \\
\hline \multirow[t]{2}{*}{ SREBP-1a } & $5^{\prime}$ & 5'-TCAGCGAGGCGGCTTTGGAGCAG-3' & \multirow[t]{2}{*}{80} & \multirow[t]{2}{*}{9} \\
\hline & $3^{\prime}$ & 5'-CATGTCTTCGATGTCGGTCAG-3' & & \\
\hline \multirow[t]{2}{*}{ SREBP-1c } & $5^{\prime}$ & 5'-GGAGGGGTAGGGCCAACGGCCT-3' & \multirow[t]{2}{*}{80} & \multirow[t]{2}{*}{9} \\
\hline & $3^{\prime}$ & 5'-CATGTCTTCGAAAGTGCAATCC-3' & & \\
\hline \multirow[t]{2}{*}{$\beta$-actin } & $5^{\prime}$ & 5'-AAGATGACCCAGATCATGTTTGAG-3' & 50 & 26 \\
\hline & $3^{\prime}$ & 5'-ACGTACATGGCTGGGGTGTTG-3' & & \\
\hline
\end{tabular}


RNA from cultured cells and animal tissues was prepared by the guanidinium thiocyanate/phenol/chloroform method (16).

Cloning of partial cDNAs encoding mouse SREBP-1 and SREBP-2. A partial cDNA encoding a fragment of mouse SREBP-1 corresponding to amino acids 36 to 378 in hamster SREBP-1 (11) was obtained by reverse transcriptase-PCR (RT-PCR) from first strand cDNA using mouse liver poly $(\mathrm{A})^{+}$RNA as a template and degenerate primers derived from conserved human (9) and hamster (11) SREBP-1 sequences, as follows: 5' primer, 5'-TCAACAACCAAGACAGTGACTTCCCTGGCC-3' ${ }^{\prime}$, corresponding to amino acids 36 to 45 in both human and hamster SREBP-1; and 3' primer, $5^{\prime}$-GTTCTCCTGCTTGAG(C/T)TTCTGGTTGCTGTG-3', corresponding to amino acids 369 to 378 in hamster SREBP-1 and 375 to 384 in human SREBP-1.

A partial cDNA encoding a fragment of mouse SREBP-2 corresponding to amino acids 13 to 460 in hamster SREBP-2 (12) was obtained by RT-PCR from first strand cDNA using mouse liver poly $(\mathrm{A})^{+}$RNA as a template and degenerate primers derived from conserved human (9) and hamster (12) SREBP-2 sequences, as follows: 5' primer, 5'-CATGGA(C/G)ACCCTCACGGAGCTGGGCGACGA-3', corresponding to amino acids 13 to 22 in both human and hamster SREBP-2; and $3^{\prime}$ primer, 5'-TGCATCATCCA $(\mathrm{G} /$ A)(C/T)AGAGG(A/G)CTTCCTGGCTC-3', corresponding to amino acids 450 to 460 in hamster SREBP-2 and 452 to 462 in human SREBP-2. All PCR products were cloned into pCRII using a TA Cloning Kit (Invitrogen Corp., La Jolla, CA) and sequenced.

Cloning of mouse sequences corresponding to 5' ends of SREBP-1a and SREBP-1c. The $5^{\prime}$ ends of mouse SREBP-1a and SREBP-1c were cloned from mouse liver poly $(\mathrm{A})^{+}$RNA by the $5^{\prime}$ rapid amplification of cDNA ends (RACE) method using a 5' RACE System kit (GIBCO-BRL, Gaithersburg, MD), AmpliTaq polymerase (PerkinElmer Cetus Corp., Norwalk, CT), and the following primers derived from the mouse SREBP-1 cDNA sequence obtained as described above. The primer for the first strand synthesis reaction was $5^{\prime}$ CTTTGCTTCAGTGCCCACCACCAGGTCTTT-3', and the nested primer for the PCR reaction was 5'-CAGGTCTTTGAGCTCCACAATCTTGTCATT-3'. The final 5' RACE product was subcloned into pCRII using a TA Cloning kit. Several clones were sequenced, and all were homologous to the $5^{\prime}$ end of human SREBP-1c cDNAs (9). To obtain the SREBP-1a clone, we probed the 5' RACE library with a ${ }^{32} \mathrm{P}$-labeled degenerate oligonucleotide derived from human and hamster SREBP-1a specific sequences (5'-CCATGGACGAGC[T/C $][\mathrm{A} / \mathrm{G}] \mathrm{CC}[\mathrm{C} / \mathrm{T}] \mathrm{TTC}[\mathrm{A} / \mathrm{G}] \mathrm{G}[\mathrm{C} / \mathrm{T}] \mathrm{GAGGCGG-3').} \mathrm{The} \mathrm{se-}$ quences of the $5^{\prime}$ ends of the mouse SREBP-1a and SREBP-1c cDNAs were used to generate 1a and 1c specific DNA templates for use in the generation of cRNA probes as described below.

RNase protection assay. The primer pairs shown in Table I were used in PCR reactions to generate cloned cDNA fragments that could be used as templates for cRNA probe synthesis. cDNA fragments for mouse SREBP-1a, SREBP-1c, SREBP-2, LDL receptor, 3-hydroxy-3-methylglutaryl (HMG) CoA synthase, HMG CoA reductase, and $\beta$-actin were amplified by PCR from first strand cDNA prepared from mouse liver poly(A) ${ }^{+}$RNA. A cDNA fragment from the mouse lipoprotein lipase mRNA was similarly isolated from mouse epididymal fat pad total RNA. cDNA fragments for human SREBP-1a and SREBP-1c were obtained from plasmid templates encoding full length cDNAs of the respective mRNAs (9). A human $\beta$-actin cDNA fragment was cloned from first strand cDNA prepared from adult human liver total RNA (Clontech). In all cases, first strand cDNA was prepared using a SuperscriptII kit (GIBCO-BRL).

Amplified cDNA fragments were subcloned into pGEM-3Zf $(+)$ or pGEM-T vector (Promega Corp.). After linearization of plasmid DNA with an appropriate restriction enzyme, antisense RNA was transcribed with $\left[\alpha-{ }^{32} \mathrm{P}\right] \mathrm{CTP}(20 \mathrm{mCi} / \mathrm{ml})$ using bacteriophage SP6 or T7 RNA polymerase (Ambion, Inc., Austin, TX). Specific activities of the transcribed RNAs were measured in each experiment and were in the range of 1.7-2.6 $\times 10^{9} \mathrm{cpm} / \mu \mathrm{g}$ for all RNAs except for $\beta$-actin RNA, which was $5.3-8.1 \times 10^{8} \mathrm{cpm} / \mu \mathrm{g}$.
Aliquots of total RNA $(10-20 \mu \mathrm{g})$ from each cell culture or tissue sample were subjected to the RNase protection assay using a HybSpeed ${ }^{\mathrm{TM}}$ RPA kit (Ambion, Inc.). Each assay tube contained a cRNA probe for the mRNA to be tested plus a cRNA probe complementary to the mRNA for $\beta$-actin. In preparing the probes, we adjusted the specific activity of the $\left[\alpha^{-}{ }^{32} \mathrm{P}\right] \mathrm{CTP}$ to give a $\beta$-actin signal comparable to the test mRNAs. After digestion with RNase A/T1, protected fragments were separated on $8 \mathrm{M}$ urea $/ 4.8 \%$ polyacrylamide gels, and the gels were dried and subjected to autoradiography using Reflection film and intensifying screens (DuPont, Wilmington, DE). The dried gels were also analyzed quantitatively with a Bio-Imaging Analyzer using BAS 1000 MacBAS software (Fuji Medical System). The level of $\beta$-actin mRNA in each RNA sample was used to normalize signals obtained for the test mRNAs. For comparison of mouse SREBP-1a, $-1 \mathrm{c}$, and -2 mRNA levels, the results were corrected for the difference in number of ${ }^{32} \mathrm{P}$-labeled cytidine phosphates in each protected fragment $(43,36$, and 47 cytidines, respectively). The protected fragments for human SREBP-1a and -1c contained the same number of ${ }^{32} \mathrm{P}$-labeled cytidine phosphates (32 cytidines).

Cell culture. All cells were grown in an $8-9 \% \mathrm{CO}_{2}$ incubator at $37^{\circ} \mathrm{C}$ except for human fibroblasts $\left(5 \% \mathrm{CO}_{2}\right)$. Monolayers of murine 3T3-L1 preadipocytes (American Type Culture Collection [ATCC] No. CCL92.1) were set up on day 0 at $1 \times 10^{5}$ cells per 100 -mm dish in $10 \mathrm{ml}$ medium A (Dulbecco's modified Eagle medium containing 100 $\mathrm{U} / \mathrm{ml}$ penicillin and $100 \mu \mathrm{g} / \mathrm{ml}$ streptomycin sulfate) supplemented with $10 \%$ (vol/vol) calf serum (Colorado Serum Co., Denver, CO). Fresh medium (10 ml/dish) was added every other day until confluence was reached on day 5 . On day 6 , differentiation was induced as described previously $(3,17)$ by supplementing the medium with $10 \%$ fetal calf serum (GIBCO-BRL), $1 \mathrm{mM}$ dexamethasone, $0.5 \mathrm{mM}$ 3-isobutyl-1-methylxanthine, and $5 \mu \mathrm{g} / \mathrm{ml}$ of insulin for $48 \mathrm{~h}$. Every other day thereafter, the cells received fresh medium supplemented only with $10 \%$ fetal calf serum and $5 \mu \mathrm{g} / \mathrm{ml}$ insulin.

Monolayers of murine NIH-3T3 cells (ATCC No. CRL-1658), HepG2 cells (ATCC No. HB-8065), and murine embryonic fibroblasts from wild-type mouse embryos at day 15.5 of gestation (18) were set up on day 0 at $5 \times 10^{5}$ cells per $100-\mathrm{mm}$ dish in $10 \mathrm{ml}$ medium A supplemented with $10 \%$ fetal calf serum and antibiotics as above. On day 1 , at $\sim 80 \%$ confluence, cells were incubated under suppressing ( + sterols) or inducing ( - sterols) conditions as previously described (6). Suppressing medium included $10 \%$ calf lipoprotein-deficient serum, $1 \mu \mathrm{g} / \mathrm{ml}$ 25-hydroxycholesterol, and $10 \mu \mathrm{g} / \mathrm{ml}$ cholesterol added in $0.2 \%$ ( $\mathrm{vol} / \mathrm{vol})$ ethanol. Inducing medium included $10 \%$ calf lipoprotein-deficient serum, $50 \mu \mathrm{M}$ compactin, 50 $\mu \mathrm{M}$ sodium mevalonate, and $0.2 \%$ ethanol. The cells were harvested $18 \mathrm{~h}$ after additions.

Monolayers of SV40-transformed and diploid human fibroblasts were set up on day 0 at $1 \times 10^{5}$ cells per 100 -mm dish in $10 \mathrm{ml}$ medium A supplemented with $10 \%$ fetal calf serum and antibiotics as above. Fresh medium was added on day 2 . On day 4, cells were incubated under suppressing ( + sterols) or inducing ( - sterols) conditions as described above. The cells were harvested either $18 \mathrm{~h}$ (SV40transformed cells) or $36 \mathrm{~h}$ (diploid cells) after additions.

Tissue survey. Tissues were pooled from 5 to $10 \mathrm{C} 57 \mathrm{BL} / 6 \mathrm{~J}$ mice at 8 wk of age, and total RNA was prepared as described (16). All human tissues except ovary and kidney were obtained at autopsy from a 21-yr-old male who died of trauma. The ovary was obtained from an 18 -yr-old female who died of unknown causes. The kidney was obtained from a 46-yr-old male who died suddenly.

Lovastatin/Colestipol diet study. C57BL/6J mice were exposed to a 14-h light/10-h dark cycle and fed either a standard $4 \%$ (wt/wt) mouse/rat diet 7001 (7001; Teklad, Madison, WI) or the same diet supplemented with $0.25 \%$ (wt/wt) lovastatin (Merck, Sharp \& Dohme) plus $2 \%(\mathrm{wt} / \mathrm{wt}$ ) Colestipol (Upjohn) for $7 \mathrm{~d}$. Mice were killed during the early light cycle in the nonfasted state.

Total RNA was prepared from mouse liver using an RNeasy ${ }^{\mathrm{TM}}$ Total RNA Kit (Qiagen). For RNase protection assay, equal aliquots of total RNA from five mice were pooled. 
A

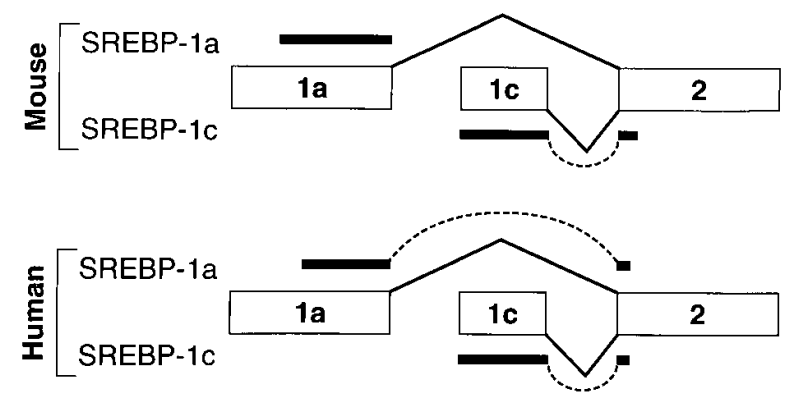

B

\section{Mouse SREBP-1a}

ATGGACGAGCTGGCCTTCGGTGAGGCGCTCTGGACAGACACTGGCCGAGATGTGGGAACTGGACACAGCG MetAsPG 1 ULeuAl aPheGlyGl UAl aA l a LeuGluGlnThrLeuAl aGl UMetCysGluLeuAspThrAla GTTTGAACGACATCGAAGACATGCTCCAGCTCATCAACAACCAAGACAGT"

ValLeuAsnAspI leGluAspMetLeuG InLeuI leAsnAsnGlnAspSer

Mouse SREBP-1c

$$
\text { Exon } 2
$$

5. - ATCGGCGCGGAAGCTGTCGGGTAGCGTCTGCACGCCCTAGGGGATCGGCGCGGACCACGGAGCC

$\overline{\text { ATGGATTGCACATTTGAAGACATGCTCCAGCTCATCAACAACCAAGACAGT }}$

MetAspCysThrPheG1 GAspMetLeuG InLeuI IeAsnAsnGinAspSer

\section{Exon 2}

Figure 1. Alternative sequences at the $5^{\prime}$ end of SREBP-1 mRNA. $(A)$ Alternative transcription start sites produce two transcripts, SREBP-1a and -1c, in which the different first exons are spliced to a common exon 2. Solid bars denote the region of the mRNA that is detected in the RNase protection assay. (B) The nucleotide and deduced amino acid sequences of the first exons of mouse SREBP-1a and $-1 \mathrm{c}$ are shown together with part of the common sequence of exon 2, which is boxed. Solid bars denote the nucleotides corresponding to the protected mRNA fragment in the RNase protection assay.

\section{Results}

Fig. $1 A$ shows the alternative forms of exon 1 in mouse and human SREBP-1. Mouse exon 1a encodes 29 amino acids, and exon $1 \mathrm{c}$ encodes 5 amino acids (Fig. $1 \mathrm{~B}$ ). A similar phenomenon occurs in the human $(9,15)$. Both exons splice into a common exon 2. For the RNase protection assay, we used cRNA probes that cover parts of exons 1a or 1c, some of which extend into exon 2 (indicated by the heavy bars in Fig. $1 A$ ).

Fig. $2 A$ shows the positions of migration of the mouse cRNA probes for exons 1a and 1c of SREBP-1 (190 and 177 nucleotodes [nt], respectively), as well as a probe for SREBP-2, which is longer than the SREBP-1 probes (264 nt). For the RNAase protection assay, total RNA from various sources was incubated with an excess of each probe, which was labeled with $\left[\alpha{ }^{32} \mathrm{P}\right] \mathrm{CTP}$. As an internal control in each assay, we included a $\left[{ }^{32} \mathrm{P}\right] \mathrm{CTP}$ labeled cRNA that hybridizes with $\beta$-actin. After hybridization had reached completion, the mixture was digested with RNase A/T1, which spares double-stranded RNA. The mixture was subjected to polyacrylamide gel electrophoresis, and the protected fragments were visualized by autoradiography and/or by phosphorimaging.

Fig. $2 B$ shows the results of an RNase protection assay using total RNA from mouse liver. The 1a and 1c probes gave rise to protected fragments of 106 and $116 \mathrm{nt}$, respectively,

\section{A Undigested 32P-Probe}

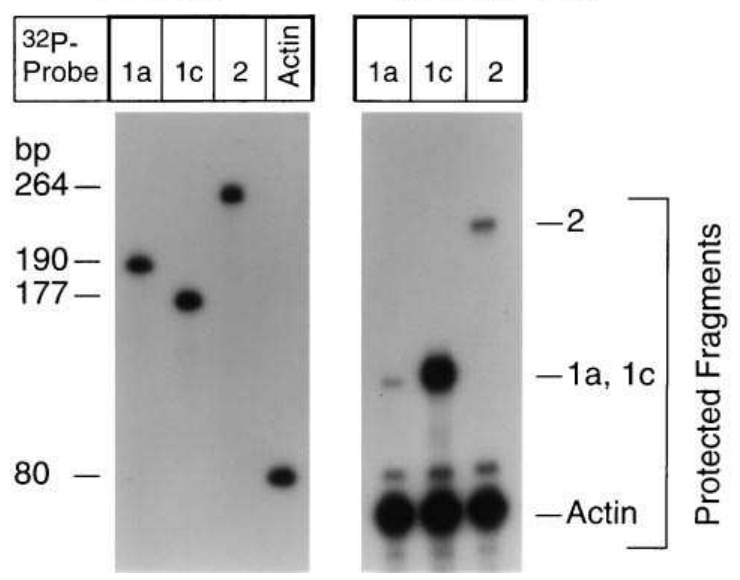

Figure 2. RNase protection assay to measure SREBP-1a, -1c, and -2 mRNAs in mouse liver. $(A)$ The positions of migration of the undigested ${ }^{32} \mathrm{P}$-labeled cRNA probes for SREBP-1a, SREBP-1c, SREBP-2, and $\beta$-actin are shown. $(B)$ Aliquots of total RNA from mouse liver $(10 \mu \mathrm{g})$ were hybridized in solution for $10 \mathrm{~min}$ at $68^{\circ} \mathrm{C}$ to the cRNA probes for SREBP-1a, SREBP-1c, or SREBP-2, all in the presence of a cRNA probe for $\beta$-actin as described in Methods. After RNase digestion, the protected fragments were separated by gel electrophoresis and exposed to film for $8 \mathrm{~h}$ at $-80^{\circ} \mathrm{C}$.

which contained 43 and 36 cytidine residues, respectively. Inasmuch as the two probes contain similar numbers of ${ }^{32} \mathrm{P}$-labeled cytidines, the relative intensities of the two bands allow a visual estimate of the relative abundance of each mRNA. Precise quantification of these protected fragments, using a BioImaging Analyzer as described in Methods, indicated that the 1c mRNA was 9.3-fold more abundant than the 1a version.

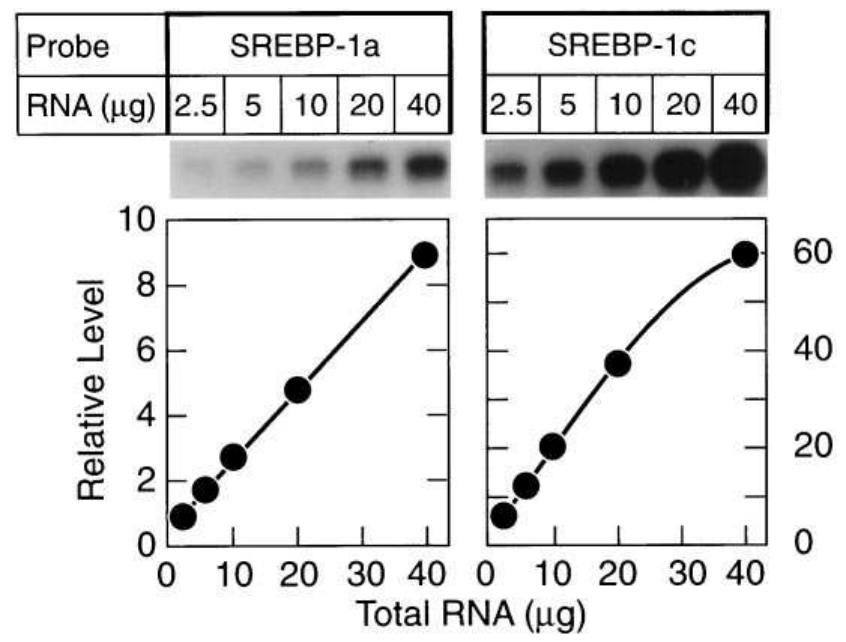

Figure 3. Linearity of signals for mouse liver SREBP-1a and -1c mRNAs in RNase protection assay. ${ }^{32} \mathrm{P}$-labeled cRNA probes for mouse SREBP-1a and -1c were hybridized to the indicated amount of total RNA from mouse liver for $10 \mathrm{~min}$ at $68^{\circ} \mathrm{C}$. Protected fragments were separated by gel electrophoresis and exposed to film for $16 \mathrm{~h}$ at $-80^{\circ} \mathrm{C}($ top $)$. The gels were also quantified in a phosphorimager as described in Methods, and the results are plotted in the lower panel. Levels of mRNA are expressed in relation to the signal for SREBP-1a at $2.5 \mu \mathrm{g}$ of RNA, which is set at 1 (left lane). 
A Mouse

\begin{tabular}{|c|c|c|c|c|c|c|c|c|c|c|c|c|c|c|}
\hline Tissue & Liv & ver & $\begin{array}{l}\text { Adre } \\
\text { Gla }\end{array}$ & $\begin{array}{l}\text { enal } \\
\text { and }\end{array}$ & $\begin{array}{r}\text { Wh } \\
F\end{array}$ & $\begin{array}{l}\text { ite } \\
\text { at }\end{array}$ & $\begin{array}{r}\text { Bro } \\
\mathrm{F}\end{array}$ & $\begin{array}{l}\text { wn } \\
\text { at }\end{array}$ & Bra & ain & Tes & & Kid & ney \\
\hline Probe & 1a & $1 \mathrm{c}$ & $1 \mathrm{a}$ & $1 c$ & $1 \mathrm{a}$ & $1 \mathrm{c}$ & $1 \mathrm{a}$ & $1 \mathrm{c}$ & $1 \mathrm{a}$ & $1 c$ & $1 \mathrm{a}$ & $1 \mathrm{c}$ & $1 \mathrm{a}$ & 1c \\
\hline Relative Level & 1 & 8.8 & 1 & 3.5 & 1 & 3.1 & 1 & 2.7 & 1 & 4.9 & 1 & 0.4 & 1 & 1.1 \\
\hline
\end{tabular}

\begin{tabular}{|l|c|c|c|c|c|c|c|c|c|c|}
\hline Tissue & \multicolumn{3}{|c|}{ Muscle } & \multicolumn{3}{|l|}{ Jejunum } & \multicolumn{3}{|c|}{ Ileum } & \multicolumn{3}{|c|}{ Thymus } & \multicolumn{3}{|c|}{ Spleen } \\
\hline Probe & $1 \mathrm{a}$ & $1 \mathrm{c}$ & $1 \mathrm{a}$ & $1 \mathrm{c}$ & $1 \mathrm{a}$ & $1 \mathrm{c}$ & $1 \mathrm{a}$ & $1 \mathrm{c}$ & $1 \mathrm{a}$ & $1 \mathrm{c}$ \\
\hline Relative Level & 1 & 2.4 & 1 & 0.5 & 1 & 0.5 & 1 & 0.7 & 1 & 0.1 \\
\hline
\end{tabular}

\section{B Human}

\begin{tabular}{|c|c|c|c|c|c|c|c|c|c|c|c|c|c|}
\hline Tissue & Liv & ver & $\begin{array}{l}\text { Adre } \\
\text { Glan }\end{array}$ & enal & Ovar & & Kidn & & Brain & $\begin{array}{c}\text { Wh } \\
\mathrm{F}\end{array}$ & & Mus & iscle \\
\hline Probe & $1 \mathrm{a}$ & $1 c$ & \begin{tabular}{l|l}
$1 \mathrm{a}$ & 1
\end{tabular} & $1 c$ & $1 \mathrm{a}$ & $1 \mathrm{c}$ & \begin{tabular}{|l|l|l|l}
$1 \mathrm{a}$ & 1
\end{tabular} & 1c & \begin{tabular}{l|l|l|l|l}
$1 \mathrm{a}$ & $1 \mathrm{c}$
\end{tabular} & $1 a$ & $1 \mathrm{c}$ & $1 \mathrm{a}$ & $1 c$ \\
\hline Relative Level & 1 & 5.8 & \begin{tabular}{l|l}
15 & 5
\end{tabular} & 5.5 & 12 & 2.8 & 10 & 0.9 & $\begin{array}{lll}1 & 2.4\end{array}$ & 1 & 2.1 & 1 & 2.0 \\
\hline
\end{tabular}

Figure 4. Distribution of mRNAs for SREBP-1a and -1c in mouse $(A)$ and human $(B)$ tissues. $(A)$ Total RNA was isolated from pooled tissues of 8-wk-old male C57BL/6J mice as described in Methods. Aliquots of total RNA $(10 \mu \mathrm{g})$ from the indicated pool were hybridized for $10 \mathrm{~min}$ at $68^{\circ} \mathrm{C}$ with the indicated ${ }^{32} \mathrm{P}$-labeled cRNA probe. After digestion with RNase, the protected fragments were separated by gel electrophoresis and exposed to film for $10 \mathrm{~h}$ at $-80^{\circ} \mathrm{C}$. (B) Aliquots of total RNA ( $20 \mu \mathrm{g}$ from all tissues except muscle [10 $\mu \mathrm{g}])$ were subjected to the RNase protection assay as described in $A$ except that the exposure to film was for $16 \mathrm{~h}$. The data for the gels in $A$ and $B$ were quantified in a phosphorimager as described in Methods and normalized for the $\beta$-actin signal. For each time point, the level of the SREBP-1c signal is shown relative to that of the SREBP-1a signal, whose value is arbitrarily set at 1 .

The amount of SREBP-2 mRNA was $37 \%$ of the value for SREBP-1c. All of these calculations were corrected for the number of ${ }^{32} \mathrm{P}$-labeled cytidines in each protected fragment and for the amount of mRNA tested, as determined from the radioactivity in the protected band for $\beta$-actin.

In experiments to validate the RNAase protection assay, we showed that the results were independent of time after the 10 min hybridization period, indicating that hybridization had reached completion (data not shown). Fig. 3 shows that the intensities of the 1a and 1c-protected fragments increased in proportion to the amount of sample RNA that was added to the incubation. Quantification of the protected fragments showed that the assay was linear for both mRNAs when up to 20-40 $\mu \mathrm{g}$ of total RNA was used. This quantitative assay confirmed that the liver contained approximately nine times as much SREBP-1c mRNA as SREBP-1a mRNA.

Fig. 4 shows the RNase-protected fragments corresponding to exons 1a and $1 \mathrm{c}$ in various tissues of the mouse and human. In both species the liver had the highest ratio of 1c:1a (six to ninefold). This ratio was also $>2.0$ in mouse adrenal, white fat, brown fat, brain, and skeletal muscle. In contrast, the 1a tran-

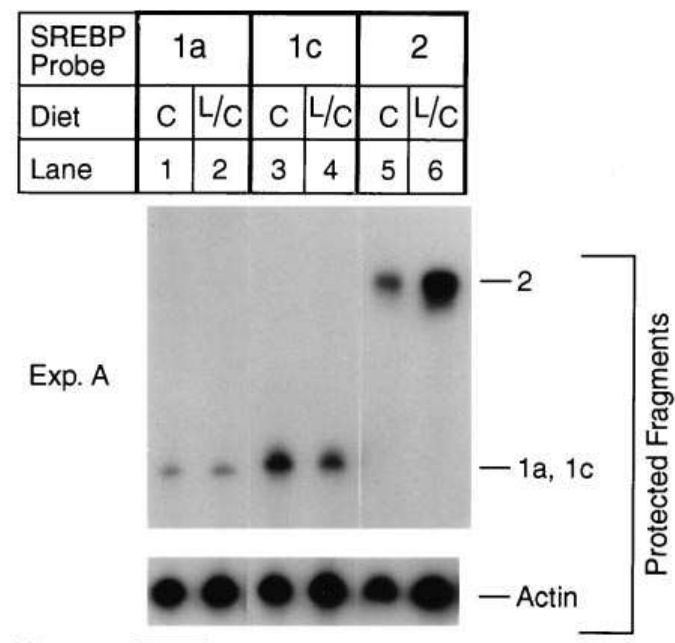

\begin{tabular}{|l|l|l|l|l|l|l|}
\hline Exp. A & - & 1.1 & - & 0.5 & - & 2.1 \\
\hline Exp. B & - & 1.1 & - & 0.6 & - & 2.3 \\
\hline \multicolumn{6}{c|}{ Fold Change }
\end{tabular}

Figure 5. Changes in the amount of mRNA for SREBP-1a, $-1 \mathrm{c}$, and -2 in livers of mice fed $0.25 \%$ lovastatin plus $2 \%$ Colestipol for $7 \mathrm{~d}$. Total RNA was isolated from the livers of five control (lanes 1,3,5) and 5 lovastatin/Colestipol-fed (lanes 2,4,6) mice as described in Methods. Aliquots of total RNA $(10 \mu \mathrm{g})$ from pooled samples from the indicated source were hybridized for $10 \mathrm{~min}$ at $68^{\circ} \mathrm{C}$ to the indicated ${ }^{32} \mathrm{P}$-labeled cRNA probe. Protected fragments were separated by gel electrophoresis and exposed to film for $8 \mathrm{~h}$ at $-80^{\circ} \mathrm{C}$. The radioactivity in the gels was quantified, normalized to the $\beta$-actin signal, and expressed as the fold change relative to the mRNA level of control mice. The quantitative results from two separate experiments are shown in the bottom panel. $C$, control; $L / C$, lovastatin/Colestipol.

script was 10 -fold higher than the 1c transcript in mouse spleen. In other tissues the amounts of the two transcripts did not differ by more than twofold. Among the human tissues that were studied, the results were similar to those in the mouse with the additional observation of a high $1 \mathrm{c} / 1 \mathrm{a}$ ratio in the ovary.

In previous experiments we showed that depletion of hepatic cholesterol by treatment of hamsters with a mixture of the HMG CoA reductase inhibitor lovastatin and the bile acid sequestrant Colestipol led to an increase in the total amount of mRNA encoding SREBP-2 and an increase in its proteolytic processing (14). In contrast, the efficiency of processing of SREBP-1 declined. We have observed similar results in C57BL/6J mice (unpublished observations). To determine whether these changes are associated with changes in the ratio of SREBP-1c:1a mRNA, we treated C57BL/6J mice with the lovastatin/Colestipol combination and then performed the RNase protection assay with hepatic RNA. The experiment was performed twice (Fig. 5, Experiments $A$ and $B$ ). Drug treatment had no significant effect on the small amount of $1 \mathrm{a}$ transcript. There was a reduction of approximately $50 \%$ in the more abundant $1 \mathrm{c}$ transcript. In contrast, the amount of the SREBP-2 mRNA increased by approximately twofold after the cholesterol depletion treatment.

Table II shows the results of the RNase protection assay applied to RNA isolated from five cultured cell lines of mouse and human origin. The cells were preincubated in two types of 
Table II. Relative Concentrations of $m R N A$ s for SREBP-1a and SREBP-1c in Cultured Cells

\begin{tabular}{|c|c|c|c|c|}
\hline \multirow[b]{2}{*}{ Cell line } & \multicolumn{2}{|c|}{+ Sterols } & \multicolumn{2}{|c|}{ - Sterols } \\
\hline & 1a & $1 \mathrm{c}$ & $1 \mathrm{a}$ & $1 \mathrm{c}$ \\
\hline & \multicolumn{2}{|c|}{ Relative level } & \multicolumn{2}{|c|}{ Relative level } \\
\hline Mouse embryo fibroblasts & 1 & 0.5 & 2.0 & 0.5 \\
\hline Mouse NIH-3T3 cells & 1 & $<0.1$ & 1.5 & $<0.1$ \\
\hline \multicolumn{5}{|l|}{ SV40-transformed } \\
\hline human fibroblasts & 1 & 0.4 & 1.8 & 0.6 \\
\hline Diploid human fibroblasts & 1 & 0.4 & 2.1 & 0.4 \\
\hline Human HepG2 cells & 1 & 0.5 & 1.7 & 0.4 \\
\hline
\end{tabular}

Cells in monolayers were set up for experiments, incubated in inducing medium ( - sterols) or suppressing medium ( + sterols), and harvested for isolation of total RNA as described in Methods. Aliquots of total RNA $(20 \mu \mathrm{g})$ were hybridzed in solution for $10 \mathrm{~min}$ at $68^{\circ} \mathrm{C}$ to ${ }^{32} \mathrm{P}$-labeled cRNA probes for SREBP-1a plus $\beta$-actin or SREBP-1c plus $\beta$-actin as indicated. Protected fragments were separated by gel electrophoresis and quantified as described in Methods. mRNA levels for SREBP-1a and $-1 \mathrm{c}$ were normalized to the $\beta$-actin signal. Values shown are expressed in relation to the level of SREBP-1a mRNA in the presence of sterols, which is set at 1 .

medium: (a) sterol suppressing medium which contained lipoprotein-deficient serum supplemented with a mixture of 25hydroxycholesterol and cholesterol; or $(b)$ sterol-deprivation medium which contained lipoprotein-deficient serum plus compactin to inhibit HMG CoA reductase and a low concentration of mevalonate to supply nonsterol end products. In sterol-supplemented medium the amount of the exon 1a transcript was greater than the $1 c$ transcript in all five cell lines. The difference became even more pronounced in sterol-depletion medium in which the amount of the 1a transcript rose by 1.5-2.1-fold without any change in the $1 \mathrm{c}$ transcript. The 1c:1a ratio was the lowest in NIH-3T3 cells, which are derived from a mouse embryo. In these cells the $1 \mathrm{c}$ transcript was undetectable. The results with human HepG2 cells were particularly striking since these cells retain many properties of the hepatocytes from which they are derived (27). Nevertheless, in tissue culture the 1a transcript predominated, whereas in the human liver the 1c transcript predominated (Fig. $4 B$ ).

To determine whether the $1 \mathrm{c}: 1$ a ratio might change during differentiation of cells in tissue culture, we studied 3T3-L1 cells, a subclone of $3 \mathrm{~T} 3$ cells that can be induced to differentiate into adipocytes by treatment with dexamethasone, insulin, and a phosphodiesterase inhibitor $(3,17)$. Kim and Spiegelman (3) demonstrated that the amount of SREBP-1/ADD1 transcript increases after adipocyte differentiation, but the 1a and $1 \mathrm{c}$ transcripts were not separately identified in their study. The autoradiograms of the RNase protection assays are shown in Fig. 6 and the quantitative analysis is shown in Fig. 7. In the undifferentiated state the 3T3-L1 cells, like the 3T3 cells, showed no detectable $1 \mathrm{c}$ transcript, and the amount of the $1 \mathrm{a}$ transcript was also relatively low (Fig. $6 \mathrm{~A}$ ). Within $1 \mathrm{~d}$ after induction of differentiation, the amount of the 1a transcript increased by nearly fivefold. It rose further over the ensuing $20 \mathrm{~d}$. During this time $>90 \%$ of the cells differentiated into adipocytes as demonstrated by staining with an Oil Red O stain. Throughout this period the $1 \mathrm{c}$ transcript was barely de-

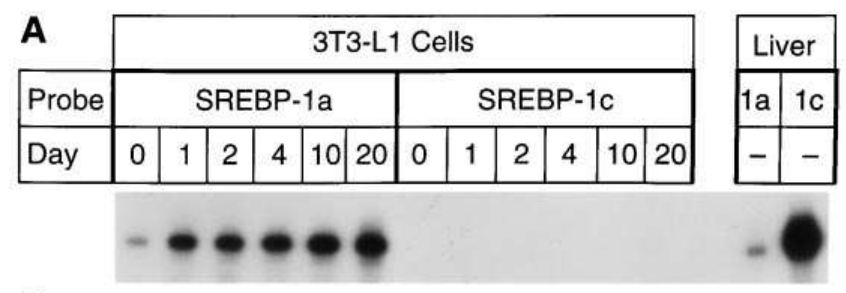

B
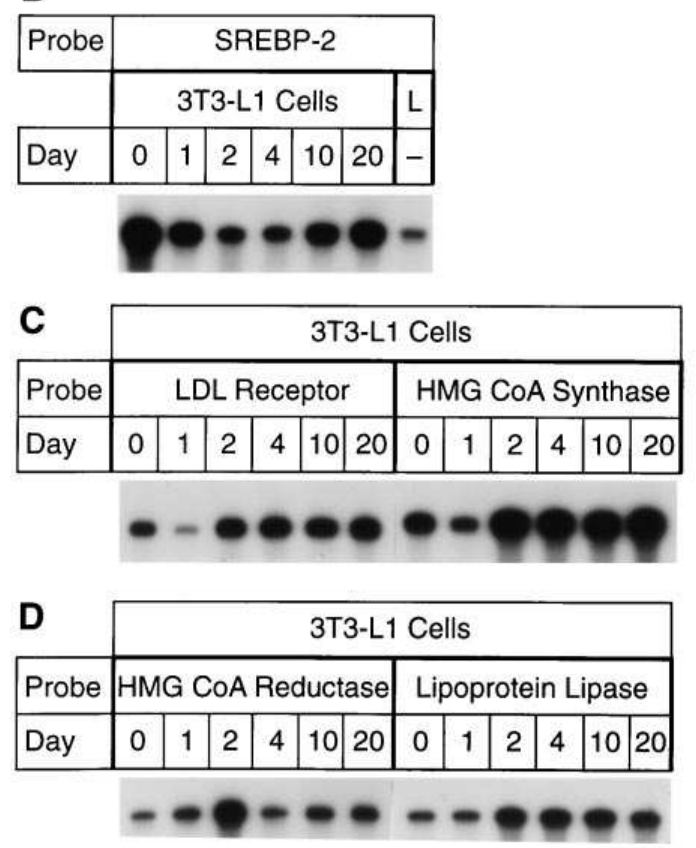

Figure 6. Induction of mRNAs for cholesterol and fatty acid-related genes during differentiation of 3T3-L1 cells. Total RNA was isolated from 3T3-L1 cells at the indicated time after treatment with differentiation medium as described in Methods. Aliquots of total RNA (20 $\mu \mathrm{g}$ ) were hybridized for $10 \mathrm{~min}$ at $68^{\circ} \mathrm{C}$ to ${ }^{32} \mathrm{P}$-labeled cRNA probes for SREBP-1a and -1c $(A)$, SREBP- $2(B)$, LDL receptor and HMG CoA synthase $(C)$, and HMG CoA reductase and lipoprotein lipase $(D)$. The right lanes in $A$ and $B$ show the results obtained when $20 \mu \mathrm{g}$ of total RNA from liver $(L)$ were hybridized with the SREBP-1a, $-1 \mathrm{c}$, and - 2 cRNA probes as indicated. Protected fragments were separated by gel electrophoresis and exposed to film for $16 \mathrm{~h}$ at $-80^{\circ} \mathrm{C}$ except for SREBP-2 and lipoprotein lipase, which were exposed for 24 and $8 \mathrm{~h}$, respectively.

tectable. For comparative purposes, Fig. $6 \mathrm{~A}$ includes a sample of adult liver studied in the same experiment, again revealing the predominance of the $1 \mathrm{c}$ transcript. In contrast to the progressive increase in the 1a transcript, the changes in the SREBP-2 transcript were biphasic (Fig. $6 B$ and Fig. $7 C$ ). The amount of this transcript was ninefold higher than that of SREBP-1a in the undifferentiated cells. It fell to a nadir at $4 \mathrm{~d}$ after differentiation, and then it rose again at days 10 and 20. The amount of the SREBP-2 transcript at days 0 and 20 was higher than the amount in the normal liver (Fig. 6, $L$ in panel $B)$. During the differentiation period there was a fivefold increase in the amount of LDL receptor mRNA and a fourfold increase in the HMG CoA synthase transcript, as quantified by RNase protection assays (Fig. $6 C$ and Fig. 7). There was also an increase in the amounts of mRNA encoding lipoprotein lipase and $\mathrm{HMG}$ CoA reductase, although the latter change was relatively modest and somewhat erratic (Fig. $6 \mathrm{D}$ and Fig. 7). 


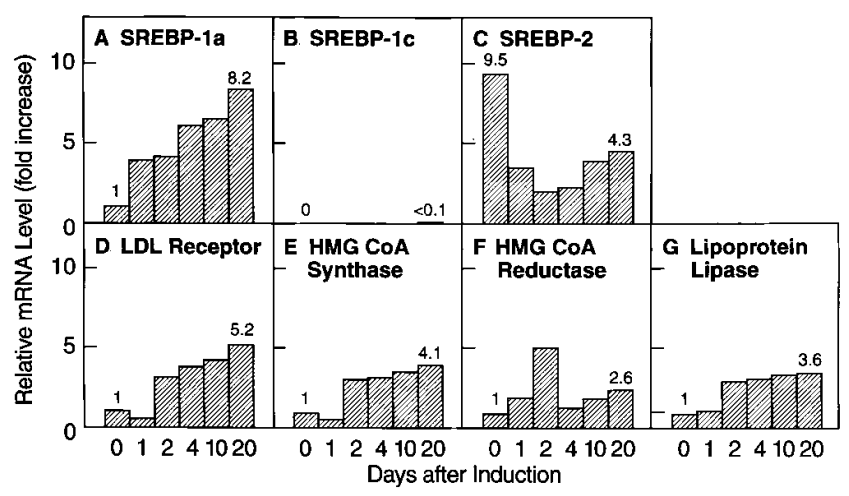

Figure 7. Quantification of mRNAs during differentiation of 3T3-L1 cells. The data from the gels in Fig. 6 were quantified as described in Methods and normalized relative to the $\beta$-actin signal. The data for SREBP-1c and -2 are plotted as the fold change relative to the SREBP-1a mRNA level on day 0. All other mRNAs are plotted as the fold change relative to their own mRNA level on day 0 .

\section{Discussion}

The current data reveal that the relative amounts of SREBP-1 transcripts containing exon 1a or 1c vary among different organs and in cultured cells. At one extreme is the mouse liver in which 1c transcripts exceed 1a transcripts by ninefold. At the other extreme is the mouse spleen in which 1a transcripts outnumber $1 \mathrm{c}$ transcripts by 10 -fold. In general, these ratios were similar in tissues from mice and humans. In five cultured lines from humans and mice the 1a transcript predominated. The most extreme example is the mouse NIH-3T3 cells, in which the 1c transcript was not detectable by the sensitive RNase protection assay that was used.

The predominance of the SREBP-1a transcript in cultured cells was not simply a matter of dedifferentiation or rapid growth. When 3T3-L1 cells were induced to stop growing and to differentiate into adipocytes, the SREBP-1a transcript rose by 8.2 -fold, and the $1 \mathrm{c}$ transcript remained virtually undetectable, even though the SREBP-1c transcript is the major form in mature adipose tissue of living mice. The rise in SREBP-1a mRNA appears to account for the previously reported rise in SREBP-1/ADD1 transcripts in 3T3-L1 cells during adipocyte conversion (3). In strict terms, however, the rise is not in ADD1, which corresponds to SREBP-1c (see Introduction), but rather it is restricted to SREBP-1a.

In recent studies, we demonstrated that SREBP-1a is much more active than SREBP-1c in stimulating transcription from SRE-1-containing promoters when the two proteins are expressed at low physiologic levels (15a). The 1c protein has a tendency to retain a greater ability to stimulate transcription of genes involved in fatty acid metabolism (fatty acid synthase, acetyl CoA carboxylase, and lipoprotein lipase) as opposed to cholesterol metabolism (HMG CoA synthase, HMG CoA reductase, and LDL receptor). This might explain why $1 \mathrm{c}$ is the predominant transcript in liver, which synthesizes more fatty acids than cholesterol, but it does not readily explain the high level of $1 \mathrm{c}$ in the adrenal gland, which synthesizes cholesterol for use in steroid hormone production. Nor does it explain the extraordinary enrichment of the 1a transcript in the spleen. The tissue measurements represent an average for all cell types within each organ. It is likely that different cell types may express different ratios of the two transcripts. Further studies will be required to fractionate organs like the spleen into different cell types (i.e., stromal cells vs parenchymal cells vs lymphocytes).

The current findings explain the observation that our laboratory isolated cDNAs that predominantly corresponded to SREBP-1a $(9,11)$, whereas Tontonoz et al. (13) isolated a cDNA encoding ADD1, which corresponds to SREBP-1c. Our cDNAs were isolated from cultured cells (human and hamster) where the 1a transcript is most abundant, whereas ADD1 was isolated from rat adipose tissue where the $1 \mathrm{c}$ transcript is presumably most abundant.

The current studies were not designed to systematically explore the regulation of SREBP-2. However, we did observe an increase in SREBP-2 mRNA in liver after treatment with Colestipol and lovastatin. This finding, coupled with the previous demonstration of an increased rate of proteolytic processing of SREBP-2 after this drug regimen (14), is consistent with a primary role for SREBP-2 in maintaining cholesterol homeostasis, as opposed to fatty acid homeostasis. In cultured cells a similar argument can be made for SREBP-1a, whose transcript rises upon sterol deprivation. SREBP-1a may not play this role in liver, however, since this transcript did not rise after sterol deprivation (Fig. 5).

Considered together, the available data indicate that the enhancers and promoters that control transcription of the genes encoding SREBP-1a, SREBP-1c, and SREBP-2 are controlled independently by regulatory elements that respond to organ-specific factors as well as to metabolic stresses. Further progress awaits an analysis of these regulatory elements and the coactivator proteins that bind to them through interaction with the three SREBPs.

\section{Acknowledgments}

We thank Constance Martinelli and Kay Richardson-Hagen for invaluable help with cultured cells; Robin Craddock for excellent technical assistance; Richard Gibson for invaluable help with animals; Jeff Cormier and Michelle Laremore for oligonucleotide synthesis and DNA sequencing; and Dr. Kitty Wyne for providing human tissue samples.

The study was supported by grants from the National Institutes of Health (HL-20948), the Moss Heart Foundation, and the Perot Family Foundation. I. Shimomura is the recipient of a research fellowship from the Manpei Suzuki Diabetes Foundation of Tokyo, Japan. J.D. Horton is the recipient of a Postdoctoral Fellowship for Physicians from the Howard Hughes Medical Institute.

\section{References}

1. Wang, X., R. Sato, M.S. Brown, X. Hua, and J.L. Goldstein. 1994. SREBP-1, a membrane-bound transcription factor released by sterol-regulated proteolysis. Cell. 77:53-62.

2. Shimano, H., J.D. Horton, R.E. Hammer, I. Shimomura, M.S. Brown, and J.L. Goldstein. 1996. Overproduction of cholesterol and fatty acids causes massive liver enlargement in transgenic mice expressing truncated SREBP-1a. J. Clin. Invest. 98:1575-1584.

3. Kim, J.B., and B.M. Spiegelman. 1996. ADD1/SREBP1 promotes adipocyte differentiation and gene expression linked to fatty acid metabolism. Genes Dev. 10:1096-1107.

4. Bennett, M.K., J.M. Lopez, H.B. Sanchez, and T.F. Osborne. 1995. Sterol regulation of fatty acid synthase promoter: Coordinate feedback regulation of two major lipid pathways. J. Biol. Chem. 270:25578-25583.

5. Ericsson, J., S.M. Jackson, B.C. Lee, and P.A. Edwards. 1996. Sterol regulatory element binding protein binds to a cis element in the promoter of the 
farnesyl diphosphate synthase gene. Proc. Natl. Acad. Sci. USA. 93:945-950.

6. Hua, X., J. Sakai, Y.K. Ho, J.L. Goldstein, and M.S. Brown. 1995. Hairpin orientation of sterol regulatory element binding protein-2 in cell membranes as determined by protease protection. J. Biol. Chem. 270:29422-29427.

7. Hua, X., J. Sakai, M.S. Brown, and J.L. Goldstein. 1996. Regulated cleavage of sterol regulatory element binding proteins (SREBPs) requires sequences on both sides of the endoplasmic reticulum membrane. J. Biol. Chem. 271: 10379-10384.

8. Sakai, J., E.A. Duncan, R.B. Rawson, X. Hua, M.S. Brown, and J.L. Goldstein. 1996. Sterol-regulated release of SREBP-2 from cell membranes requires two sequential cleavages, one within a transmembrane segment. Cell. 85 : 1037-1046.

9. Yokoyama, C., X. Wang, M.R. Briggs, A. Admon, J. Wu, X. Hua, J.L. Goldstein, and M.S. Brown. 1993. SREBP-1, a basic helix-loop-helix leucine zipper protein that controls transcription of the LDL receptor gene. Cell. 75: 187-197.

10. Hua, X., C. Yokoyama, J. Wu, M.R. Briggs, M.S. Brown, J.L. Goldstein, and X. Wang. 1993. SREBP-2, a second basic-helix-loop-helix-leucine zipper protein that stimulates transcription by binding to a sterol regulatory element. Proc. Natl. Acad. Sci. USA. 90:11603-11607.

11. Sato, R., J. Yang, X. Wang, M.J. Evans, Y.K. Ho, J.L. Goldstein, and M.S. Brown. 1994. Assignment of the membrane attachment, DNA binding, and transcriptional activation domains of sterol regulatory element binding protein-1 (SREBP-1). J. Biol. Chem. 269:17267-17273.

12. Yang, J., R. Sato, J.L. Goldstein, and M.S. Brown. 1994. Sterol-resistant transcription in CHO cells caused by gene rearrangement that truncates SREBP-2. Genes Dev. 8:1910-1919.

13. Tontonoz, P., J.B. Kim, R.A. Graves, and B.M. Spiegelman. 1993. ADD1: a novel helix-loop-helix transcription factor associated with adipocyte determination and differentiation. Mol. Cell. Biol. 13:4753-4759.

14. Sheng, Z., H. Otani, M.S. Brown, and J.L. Goldstein. 1995. Independent regulation of sterol regulatory element binding proteins 1 and 2 in hamster liver. Proc. Natl. Acad. Sci. USA. 92:935-938.

15. Hua, X., J. Wu, J.L. Goldstein, M.S. Brown, and H.H. Hobbs. 1995. Structure of human gene encoding sterol regulatory element binding protein-1 (SREBF1) and localization of SREBF1 and SREBF2 to chromosomes 17p11.2 and 22q13. Genomics. 25:667-673.

15a. Shimano, H., J.D. Horton, I. Shimomura, R.E. Hammer, M.S. Brown, and J.L. Goldstein. 1997. Isoform 1c of sterol regulatory element binding protein is less active than isoform 1a in livers of transgenic mice and in cultured cells. J. Clin. Invest. 99:846-854.

16. Chomczynski, P., and N. Sacchi. 1987. Single-step method of RNA isolation by acid guanidinium thiocyanate-phenol-chloroform extraction. Anal. Biochem. 162:156-159.

17. Lin, F.-T., and M.D. Lane. 1992. Antisense CCAAT/enhancer-binding protein RNA suppresses coordinate gene expression and triglyceride accumulation during differentiation of 3T3-L1 preadipocytes. Genes Dev. 6:533-544.

18. Willnow, T.E., A. Rohlmann, J. Horton, H. Otani, J.R. Braun, R.E. Hammer, and J. Herz. 1996. RAP, a specialized chaperone, prevents ligandinduced ER retention and degradation of LDL receptor-related endocytic receptors. EMBO (Eur. Mol. Biol. Organ.) J. 15:2632-2639.

19. Hoffer, M.J.V., M.M. van Eck, F. Petrij, A. van der Zee, E. De Wit, D. Meijer, G. Grosveld, L.M. Mavekes, M.H. Hofker, and R.R. Frants. 1993. The mouse low density lipoprotein receptor gene: cDNA sequence and exon-intron structure. Biochem. Biophys. Res. Commun. 191:880-886.

20. Gil, G., J.L. Goldstein, C.A. Slaughter, and M.S. Brown. 1986. Cytoplasmic 3-hydroxy-3-methylglutaryl coenzyme A synthase from the hamster: I. Isolation and sequencing of a full-length cDNA. J. Biol. Chem. 261:3710-3716.

21. Osono, Y., L.A. Woollett, J. Herz, and J.M. Dietschy. 1995. Role of the low density lipoprotein receptor in the flux of cholesterol through the plasma and across the tissues of the mouse. J. Clin. Invest. 95:1124-1132.

22. Chin, D.J., G. Gil, D.W. Russell, L. Liscum, K.L. Luskey, S.K. Basu, H. Okayama, P. Berg, J.L. Goldstein, and M.S. Brown. 1984. Nucleotide sequence of 3-hydroxy-3-methylglutaryl CoA reductase, a glycoprotein of the endoplasmic reticulum. Nature (Lond.). 308:613-617.

23. Luskey, K.L., and B. Stevens. 1985. Human 3-hydroxy-3-methylglutaryl coenzyme A reductase: conserved domains responsible for catalytic activity and sterol-regulated degradation. J. Biol. Chem. 260:10271-10277.

24. Kirchgessner, T.G., K.L. Svenson, A.J. Lusis, and M.C. Schotz. 1987. The sequence of cDNA encoding lipoprotein lipase: a member of a lipase gene family. J. Biol. Chem. 262:8463-8466.

25. Tokunaga, K., H. Taniguchi, K. Yoda, M. Shimizu, and S. Sakiyama. 1986. Nucleotide sequence of a full-length cDNA for mouse cytoskeletal $\beta$-actin mRNA. Nucleic Acids Res. 14:2829.

26. Ponte, P., S.-Y. Ng, J. Engel, P. Gunning, and L. Kedes. 1984. Evolutionary conservation in the untranslated regions of actin mRNAs: DNA sequence of a human beta-actin cDNA. Nucleic Acids Res. 12:1687-1696.

27. Knowles, B.B., C.C. Howe, and D.P. Aden. 1980. Human hepatocellular carcinoma cell lines secrete the major plasma proteins and hepatitis B surface antigen. Science (Wash. DC). 209:497-499. 